\title{
CONTRIBUIÇÃO AO ESTUDO ANATOMICO DE CURATELLA AMERICANA L.
}

\author{
DELPHOS JOSÉ GUIMARÃES • \\ ROSANGELA RAMOS DE ARAÚNO ** \\ BENEDICTO A. DUARTE DE OLIVEIRA * \\ HONORIO MONTEIRO NETO *
}

existe A espécie usada no presente estudo, Curatella americana L. fam. Dilleniaceae, da qual

trazidas exemplar vivo no Jardim Botânico do Rio de Janeiro, cultivada a partir de sementes do cerrado de Paraopeba Estado de Minas Gerais.

ârbustos Habita por todo Brasil tropical, em lugares secos subestéreis, associada a pequenas árvores e

Gaducifolia que sâo chamados tabuleiros cobertos e tambèm na orla das caatingas, onde se torna

Perto de Fstado de São Paulo, parte setentrional, nos Estados de Minas Gerais, em Cerro Frio,

$S_{\Xi_{0}}$ Fra Formiga e também entre Borda do Campo e Ouro Preto, na parte ocidental até o Rio

Princiancisco. Pelo Estado de Goiás até Mato Grosso na altura de Cuiabá. De Vitória até a Bahia Nalmente em lugares arenosos, tambèm no Piaul, Maranhăo e Para (ob. dos autores).

Carajás Nomes vulgares: lixeira, cajueiro bravo, cajurana, sambaiba (do Tupi Caimbé áspero). Os As

Madeira. As folhas såo empregadas como papel de lixa, no polimento e desgaste de objetos de

infectados E utilizada ainda em veterinária e em medicina humana no tratamento de ferimentos dos. (FI. Bras. $13(1)$ : 67-69.

As folhas, quanto à sua morfologia, sāo:

inteiras. Folhas elipticas as vezes oblongas, obtusas às vezes arredondadas, mais ou menos plicadas

toment Repandas as vezes sinuato dentada (grosso crenada), superiormente (pag. ventral) áspera Fiosa às vezes âsperas.

Folhas fechadas para o ápice do ramo, as mais jovens agradavelmente tomentosa, pelos
quisciculados estelados, bastante rijos as vezes alongados e flexíveis o indumento torna-se áspero e

Como os pélos são mais espaçados menor é a aspereza. O tamanho dos pélos é variado, bem

comprimespaçamento entre eles e o tamanho das folhas varia de $7,6 \mathrm{~cm}$ a $30,5 \mathrm{~cm}$ de

hervira

12 a central bem desenvolvida, dorsalmente semicilindrica. Nervuras secundárias em número de

dorralmento patentes e prolongam-se em apiculos marginais. Ventralmente săo subimpressas, e A

Aparecem pêlos estelados em todas as nervuras, sð̃o persistentes.

\section{MATERIAL E MÉTODOS}

Parape exemplar estudado acha-se registrado sob o n. 7793 e é oriundo de sementes trazidas de

Essos Estado de Minas Gerais e consta de terço medio, peciolo e bordo da folha.

fixadoressas regiōes foram incluídas em parafina pelos métodos usuais utilizando-se como cortes fes F.P.A. e F.A.A. As preparações foram obtidas pelas técnicas histologicas usuais e os utados feitos em micrótomo rotatório de Reichert, com 10 e 15 micra de espessura. Os corantes Lados foram hematoxilina de Delafield-Fast green e Safranina hidroalcoólica - Fast green.

- Pesquisadores do Jardim Botànico do Rio de Janeiro e Bolsistas do CNPq

Professor Assistente do Instituto de Biocièncias Exatas UNESP

Rodriguésia
Rio de Janeiro

ANO $X X X I 1-N O 52$ 1980 
Na dissociação das epidermes utilizamos ácido nítrico $1 / 3$ e clorato de potássio a quente As fotomicrografias foram feitas no microscópio ortolux Ernst Leitz Wetzlar, com filtro amarti n? 15 em càmera Leica, utilizando-se filme IIford 50 ASA

\section{DESCRIÇĀO ANATOMICA}

\section{Limbo Foliar:}

Folha dorsiventral, com espessura média de 300 micrômetros. As epidermos sð̄o uniestr? tificadas e constituídas de células achatadas mais ou menos poliédricas, com cutícula espesst. cutinizaç̄o é muito desenvolvida principalmente na regiảo dos bordos e nas nervuras em que ${ }^{\circ}$ processo se insinua pelas paredes anticlinais. Apenas a epiderme inferior apresenta estômatos, of quais săo do tipo anomocítico. Em ambas as epidermes existem quatro tipos básicos de pellof cujas paredes s.o extremamente reforçadas, havendo transição contínua entre os tipos.

Esses tipos são: a) pêlos muito curtos com altura variando desde um pouco mais que ? altura de célula epidérmica, até um máximo de 40 micrômetros. Esses pêlos săo formados por conjunto de células que se aguçam lateraimente em suas extremidades, contendo até 20 célulps (fotos 1 e 2); b) pellos estelados, com poucas ou muitas cellulas alongadas, em geral até 20, qua divergem de um ponto. Suas células apresentam uma base alta, que é a parte mais larga, e continua por uma parte afilada que parte inclinadamente da base, de luz muito estreita (foto ${ }^{3}$. c) tipo misto, que é formado de células curtas iguais às do pêlo curto e de células longas iguais do pelo estelado - o número de células curtas e de células longas é variável (foto 4); d) pél simples - este é sempre longo e de lúmen estreito.

Os pélos curtos sảo mais numerosos e mais desenvolvidos na epiderme superior (foto 51 : ff os estelados e os mistos o são na inferior (foto 6). Os pêlos simples são mais freqūentes nî epiderme inferior das nervuras.

\section{Mesofilo:}

No mesbfilo (foto 7), o tecido paliçadico uniestratificado, mas, frequeentemente subdivide (foto 8); o tecido lacunoso é formado de poucas camadas de células, em geral, até 4 ; regiß̋ das nervuras e dos bordos, ambas se interrompem totalmente na presença de outros tecidos

\section{Nervura Mediana:}

A nervura mediana (foto 9), apresenta-se com contorno circular ao nivel do terço médio, com costa mais pronunciada nas imediaçōes do pecíolo. Sua epiderme é fortemente cutinizada formada de células longas mais altas que largas; na superior as células tếm a parede periclin externa bem convexa e com cutícula lisa ou ondulada; na epiderme inferior a parede externa" releva, mas apresenta-se com saliências na cutícula, à maneira de cristas (foto 10).

Junto às epidermes, há um colênquima provido abundantemente de cloroplastos, com cerê de 4 a 5 camadas, de tipo misto, mais próximo do tipo angular; mais para dentro o parénquint? cortical, com parede fina, além de apresentar uma quantidade expressiva de cloroplastos, apresenth também cbllulas com ráfides de oxalato de cálcio que nos cortes aparecem em quantidadel exageradas.

Contornando floema e xilema, há um parênquima de cólulas esclerificadas (foto 11), parede grossa e de lámen largo, a maneira de um escrerênquima, com o qual à primeira visth facilmente se confunde.

Esse parênquima apresenta bastante cloroplastos e às vezes uma granulaçăo grosseira, cuj fo grãos são do tamanho dos cloroplastos ou bem maiores, até cerca de 4 vezes; esses grăos que aqueles, e, parecem ser mais freqūentes nos mais profundos estratos do parénquima.

Em cortes longitudinais, as células desse parénquima se mostram cillindricas longas e curt prosenquimatosas com paredes ricas de pontuaçōes, inclusive nos septos que podem perpendiculares, e de inclinação muito variável; muitas vezes, um dos septos da célula n apresenta a parede grossa e pontuada, mas sim uma parede muito fina.

O floema contínuo, em círculo, apresenta todos os seus elementos bem conspicuor: relativamente grandes, e com conteúdo densamente corável. O xilema é praticamente continuo 
tm círculo, se interrompe às vezes por um parênquima; seu parênquima radial quase sempre apresenta células de paredes esclerificadas e freqüentemente com cloroplastos e bem providas de Iranulação grosseira, a granulação jấ citada para o parênquima cortical esclerificado.

ráficdes. $\mathrm{Na}$ regiåo medular as células sЈjo muito grandes, e ainda säo providas de cloroplastos e com e 3, com pessa regiäo há esclerócitos bem desenvolvidos, arredondados, isolados ou em grupos de 2 com pontuações grandes. Feixes subsidiários af são frequeentes e bem desenvolvidos (foto 12). Darênquis nervuras secundárias (foto 13), o colênquima e parênquima cortical fundamental e onde a costa értical esclerificado da regiäo adaxial ss̃o menos desenvolvidos que na regiāo abaxial, No

No seio do colênquima e do parênquima cortical da regiảo abaxial várias lacunas podem ser rvadas.

Nas nervuras de ordem superior, o parénquima esclerificado é o tecido mais representativo giš̉o adaxial, e o colênquima o é na abaxial.

Nos bordos da folha os tecidos paliçádico e lacunoso se limitam com um colênquima bem desenvolvido, com cloroplastos, podendo af as nervuras estar ou não em contato direto com o colênquima, Pelos de todos os tipos podem ai estar presentes.

Peciolo:

(foto pecíolo se apresenta com limbo recorrente e com forma semicircular em seção transversal, vezes, 14). Sua epiderme é constituida de células papilosas, muitas vezes subdivididas 2,3 ou 4 ou ramificadas ou não, com aspecto de vilosidades, com núcleo bem conspícuo, cutícula mais menos espessa, com aspecto de uma epiderme secretora (foto 15).

Oflulas conjuntos tricomatbides dessa epiderme podem ter ramificaçăo lateral ou dicotòmica; as do ápice podem ser maiores ou menores que as subjacentes.

O colênquima do pecíolo é também rico de cloroplastos, bem como o parênquima cortical. parénquima esclerificado é muito reduzido ou deixa de existir totalmente.

oxalato corte a fresca o parìnquima mostra também quantidade exagerada de rafides de de calcio.

Os feixes no pecíolo já se tornam isolados, em círculo.

\section{DISCUSSĂO}

timples estudo anatOmico da folha de Curatella americana L. revelou tratar-se de uma estrutura tipos dos xeromorfa, curiosa sob certos aspectos, como no caso de apresentar tricomas de vários âcentuada quais o curto, o estelado e o misto são típicos da espécie; os pêlos dão à folha uma

Essa propriedade possibilitou o uso de polir madeiras, metais e arear utensflios de cozinha

Record, 1943). A razäo da aspereza esta no fato de ser a folha rica em silica (Corrèa 1926; d, 1943).

A folha 6 mais áspera na face adaxial, onde sỉo mais numerosos os pêlos curtos.

en 0 colênquima, sempre se apresenta com cloroplastos, independentemente da regījo da folha que aparece.

haver Foram examinadas folhas de sombra e folhas de sol e em ambos os casos pareceu-nos nāo

er diferença quanto a quantidade de cloroplastos do colenquima.

tanoide Foram feitos testes microquímicos com cloreto férrico a $10 \%$ ficando evidenciado conteúdo para todos os tecidos.

Parếnquimam também realizados testes para identificaçăo da granulaçăo grosseira presente no

hatureza esclerificado e nenhum deles nos pode fornecer dados suficientes para identificaça da química dos corpúsculos.

\section{SUMMARY}

The leaf of Curatel/a americana L. is scleromorphic with anomocytic stoma on the abaxial $\mathrm{L} 0 \mathrm{ng}$, sim and with four types of thick walled cells of which three are characteristic of the species: a) of cells simple hairs principally on the nerves on the abaxial side; b) Short hairs formed of a series cells (up to 20) with short, pointed apical saliences, best developed on the adaxial epidermis; 
c) Stellate hairs, formed of a series of cells and having a short and a long, slender latery projection; d) Mixed hairs with short cells, as in the short hairs, and long cells as in the stellate type.

The epidermises are impregnated with silica, the adaxial epidermis being extremely rough.

The palisade tissue is single layered but frequently is subdivided, and on the margins of the blade there occurs a well developed colenchyma with chloroplasts.

The midvein has epidermal cells with crest like cuticular saliences, with the 4 types of hairs; the cortical region has collenchyma and parenchyma well provided with chloroplasts and ? sheath of long-celled, sclerified parenchyma which completely surrounds the vascular bundles and which has chloroplasts. The phloem and xylem form continuous or nearly continuous circles. The medular parenchyma has some subsidiary vascular bundles, grouped, spherical sclereids and large quantities of raphides of calcium oxalate.

The petiole, with decurrent blade, has a structure similar to the midveins, but the slerfied parenchyma is absent or nearly absent. The epidermal cells are papillose and can appear to be 24 times divided forming simple trichome-like assemblages or with dichotomous or lateral branches.

Fresh cuts of the rachis and petiole reveal great quantities of needle-like crystals of calcium oxalate, as well as the presence of much tanin in the tissues when the reaction tests is made with $10 \%$ ferric chloride.

\section{BIBLIOGRAFIA}

1. CORREA, M.P. Dicionário das Plantas úteis do Brasil e das Exóticas Cultivadas Publ. M Agricultura, Rio de Janeiro, 1:402, 1926.

2. EICHLER, A. G. Dillenieaceae in F1. Bras. 13(1):67-69; 1841-1872.

3. MACHADO, Q $\times B R$. Botânica Plantas do Brasil Central, Dep. Imp. Nac., Rio de Janeiro Brasil: 31-32; estampas 41-42, 1954.

4. METCALFE, C.R., and L CHALK. Anatomy of the Dicotyledons. Ed. 2 vols., Clarendon Press, Oxford, 1950.

5. MORRETES, B.L., and FERRI, M.G.; 1959, Anatomia de Plantas do Cerrado, in Bol. Fac. Fih. Clênc. Letr. USP, Botânica 16 (Bol. 243):7-70.

6. RECORD, S.J. and HESS, R.W. Timbers of the New World, New Haven, Yale Univ. Press. $141-143,1943$.

7. RIZZINI, C.T" A Flora do Cerrado, Separata do Vol. "Simpósio sobre o Cerrado". Editora d" Univ. de Säo Paulo, 127-177, 1963. 


\section{EXPLICAÇĀO DA ESTAMPA}

1. Fotomicrografia de um pêlo curto $450 x$

2. Fotomicrografia de um pelo simples da epiderme adaxial $450 \mathrm{x}$

3. Fotomicrografia de um pêlo estelado $450 x$

4. Fotomicrografia de um pêlo misto $450 \mathrm{x}$

5. Fotomicrografia da epiderme superior $100 x$

6. Fotomicrografia da epiderme inferior $100 \mathrm{x}$

7. Fotomicrografia mostrando tecido paliçadico uniestratificado $100 \mathrm{x}$

8. Fotomicrografia regiāo do mesófilo mostrando paliçadico subdividido

9. Fotomicrografia da nervura mediana $50 x$

10.

Fotomicrografia da epiderme inferior da nervura mediana mostrando saliências na crista da
cutícula $450 x$

11. Fotomicrografia do parênquima esclerificado evidenciando granulaç̋̃es $450 \mathrm{x}$

12. Fotomicrografia de um corte ao nível da nervura mediana mostrando feixes subsidiários

13. Fotomicrografia da nervura secundária evidenciando lacunas no parènquima cortical

14.

\section{Fotomicrografia do pecíolo $50 \mathrm{x}$}

15.

16.

Fotomicrografia da epiderme papilosa do pecíolo $450 \mathrm{x}$

Fotomicrografia do pecíolo mostrando feixes subsidiários 

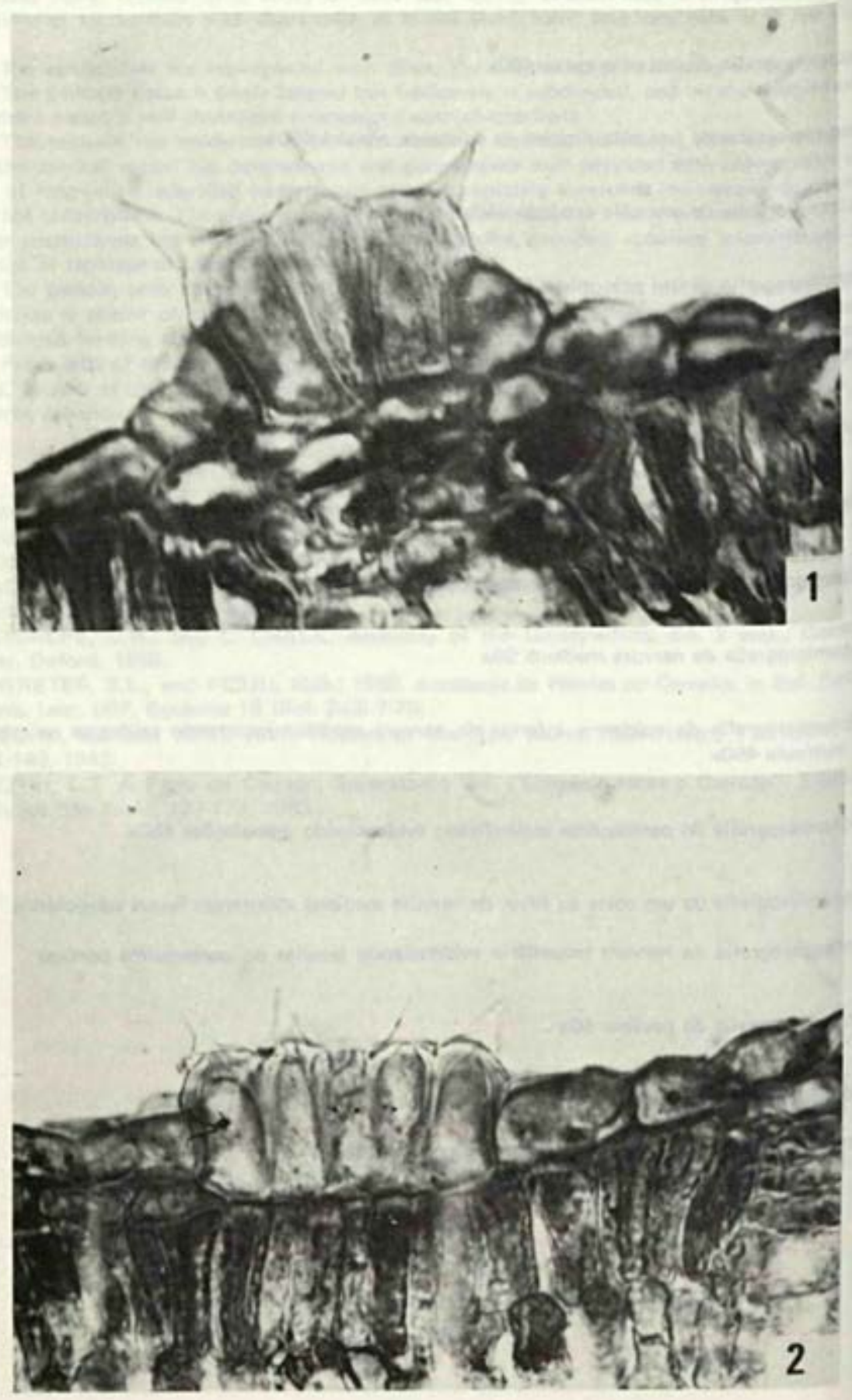

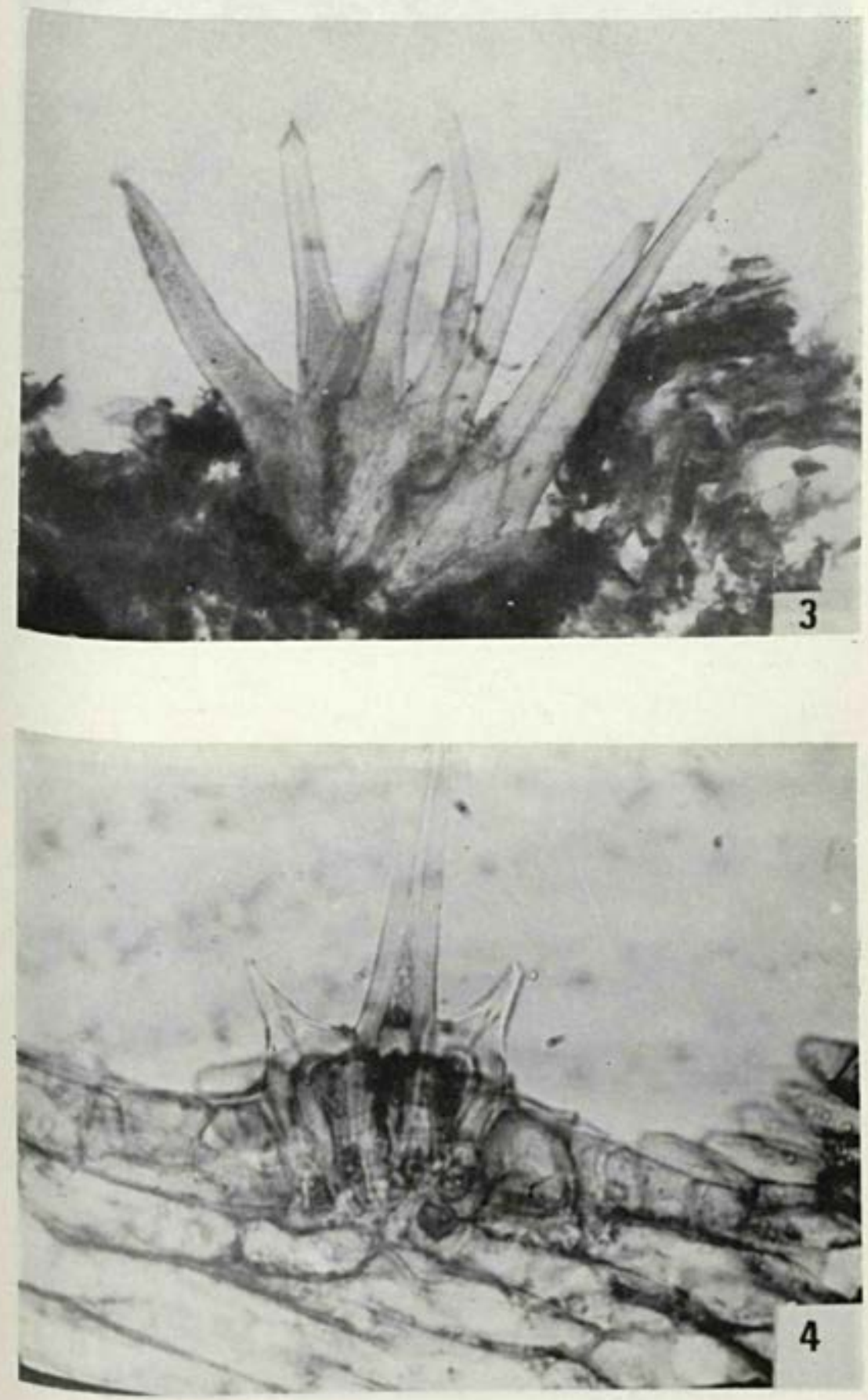

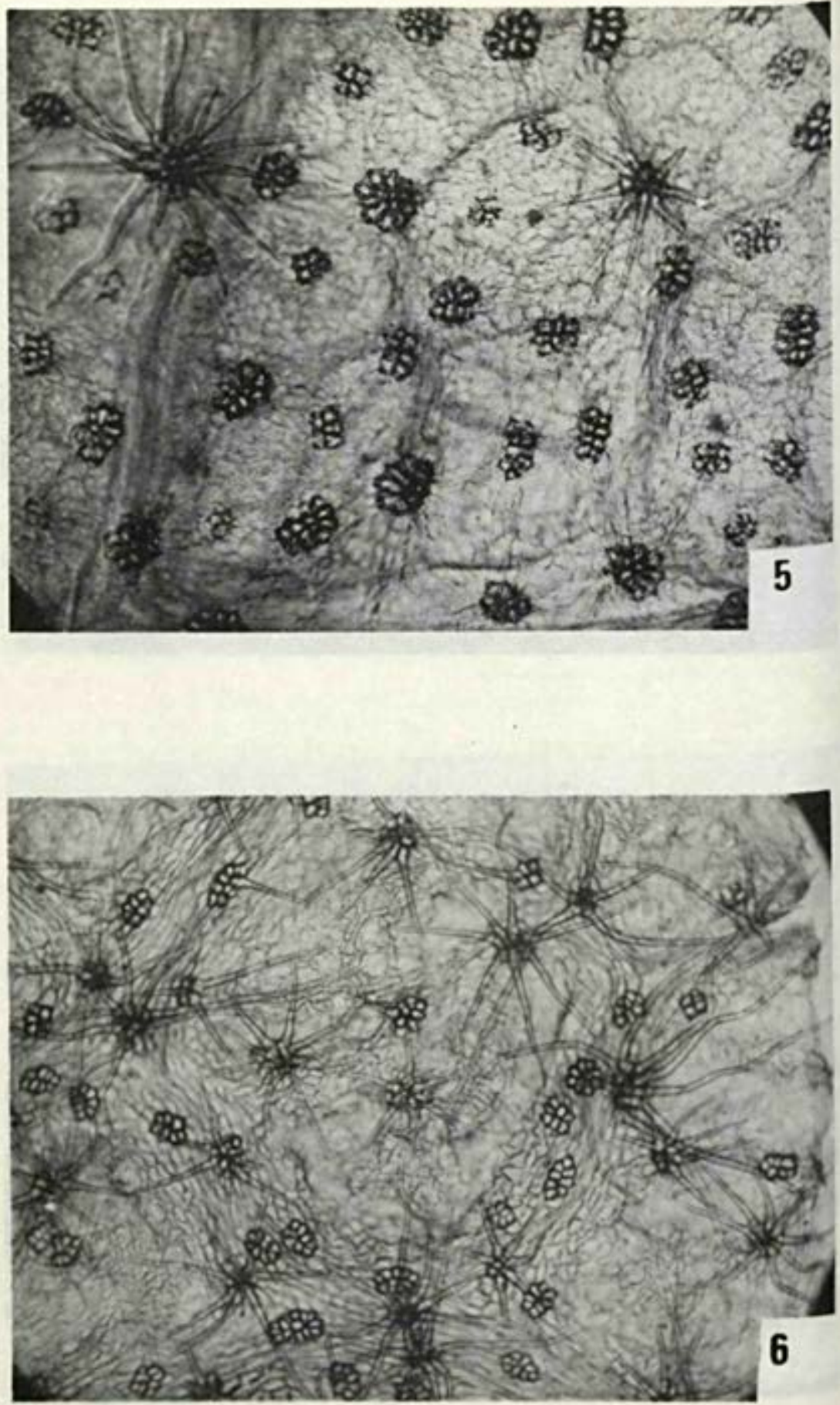

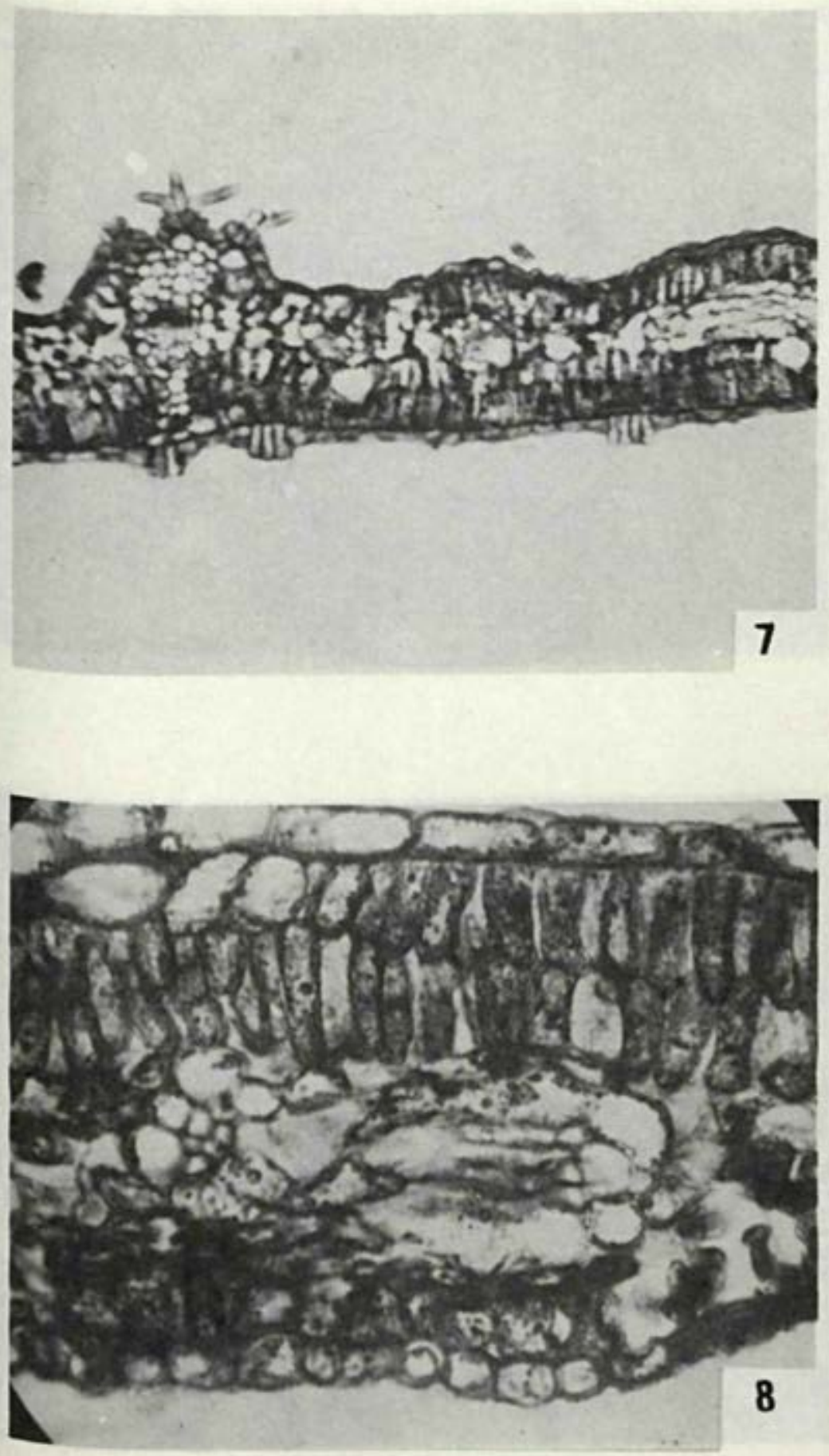

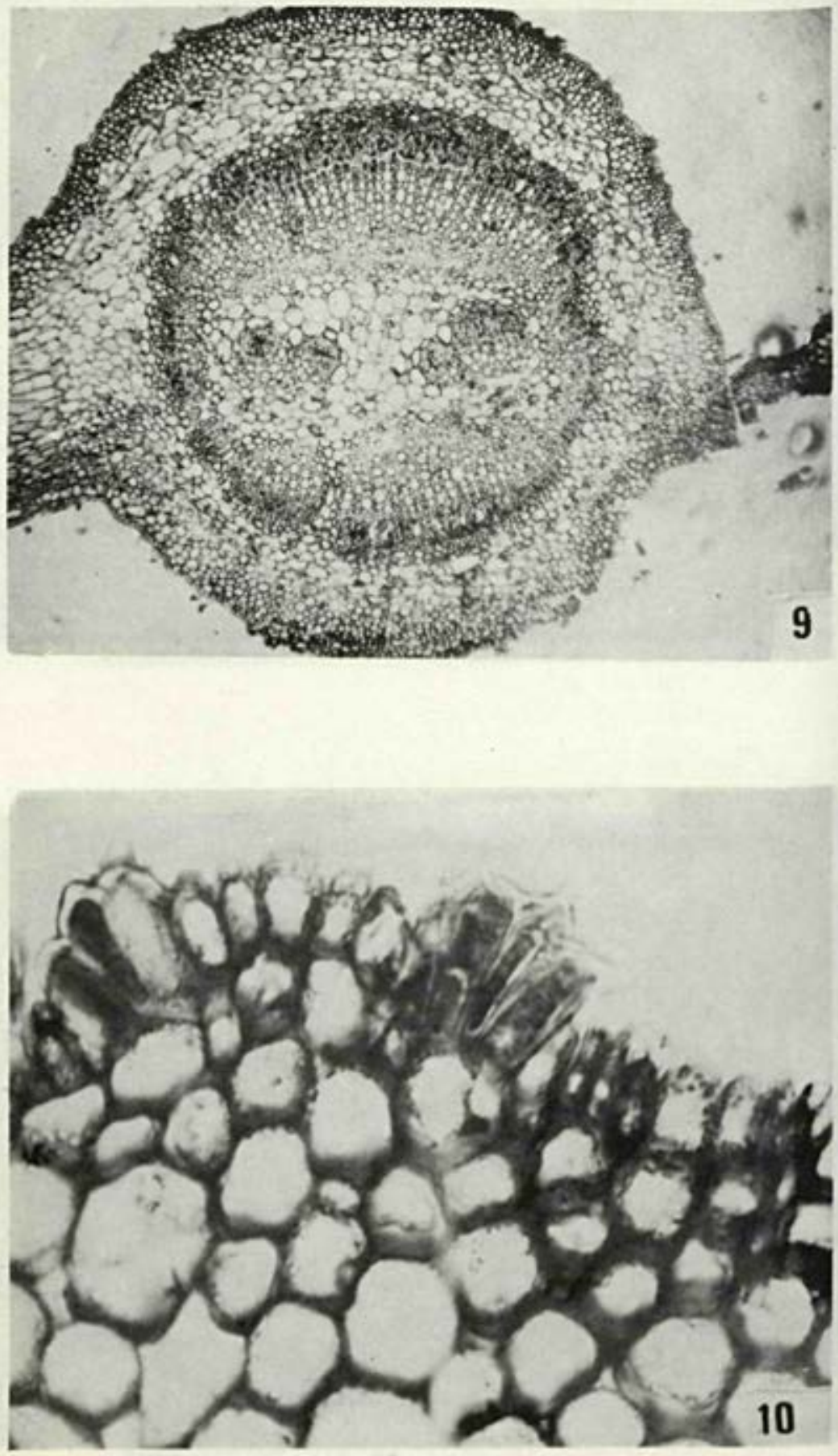

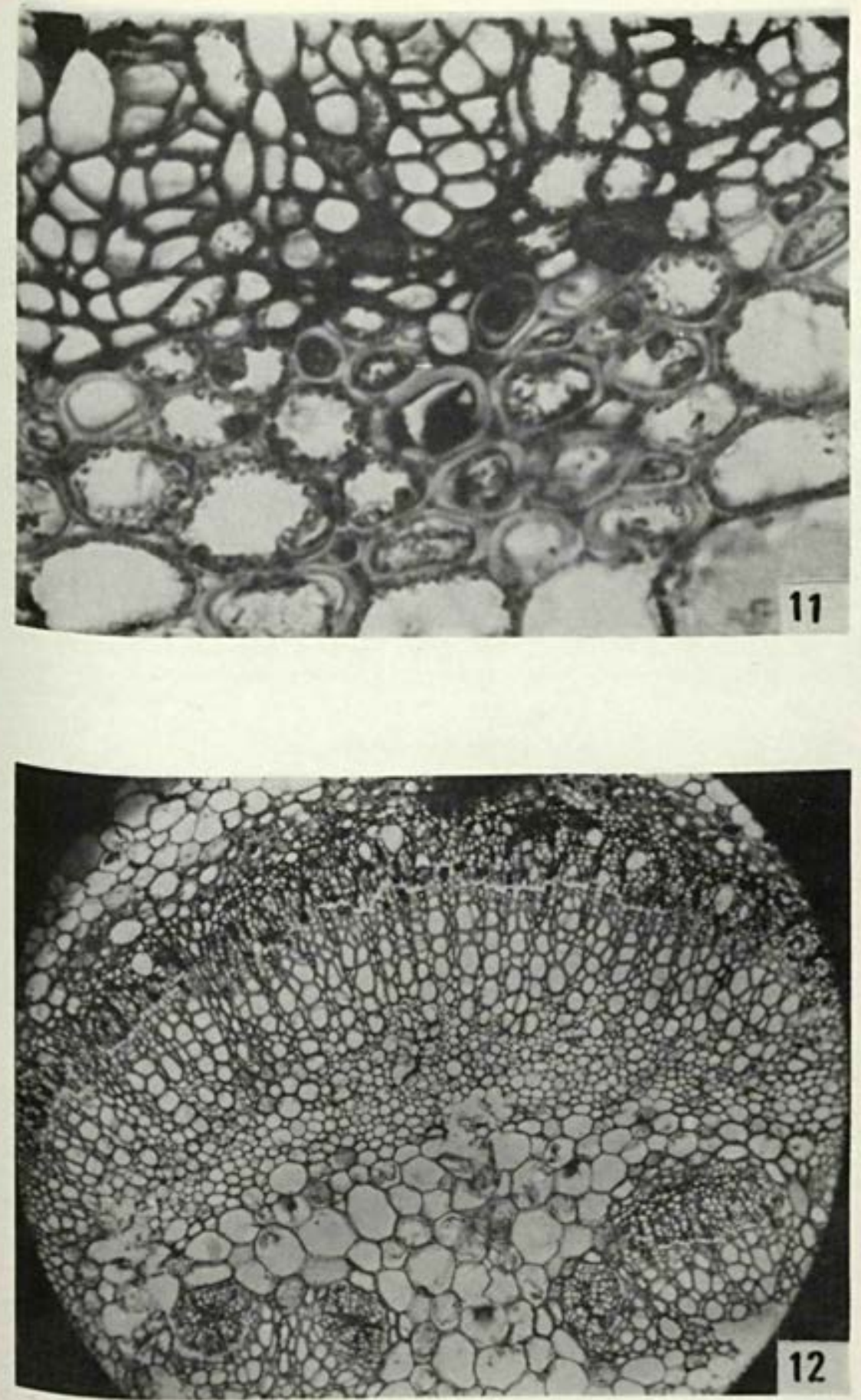

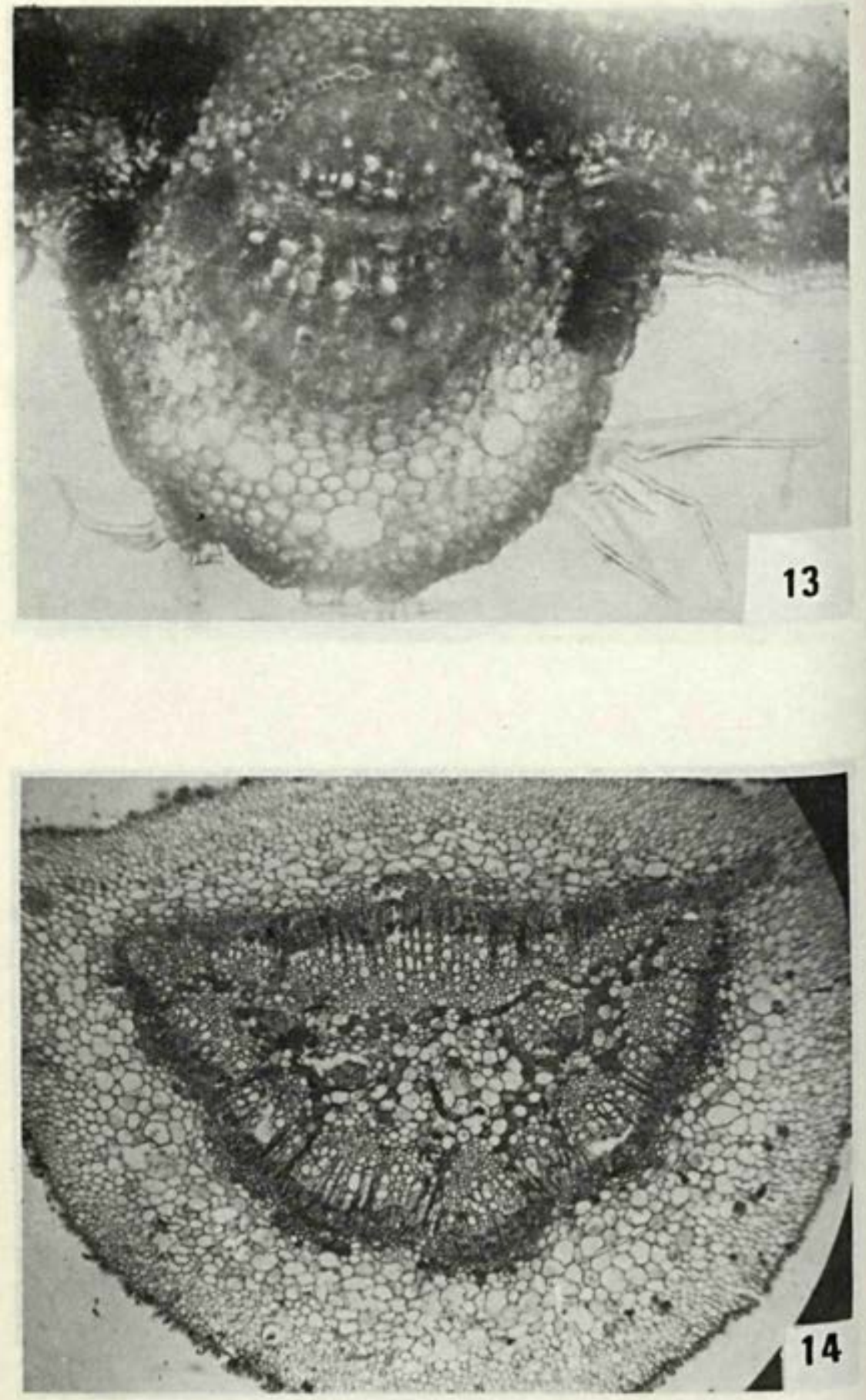

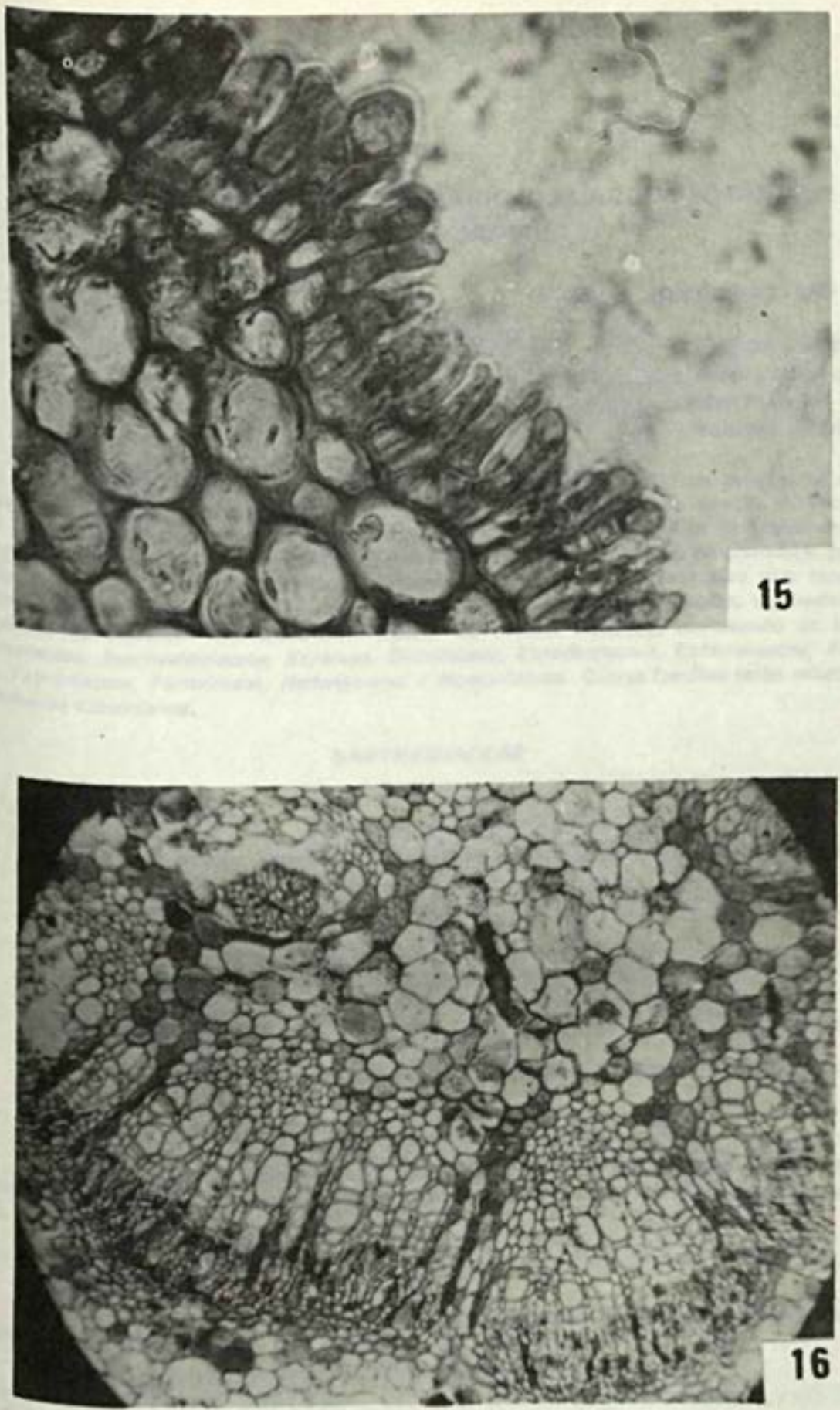